\title{
Front Matter: Volume 10899
}

, "Front Matter: Volume 10899," Proc. SPIE 10899, Components and Packaging for Laser Systems V, 1089901 (16 May 2019); doi: $10.1117 / 12.2531302$

SPIE. Event: SPIE LASE, 2019, San Francisco, California, United States 


\title{
PROCEEDINGS OF SPIE
}

\section{Components and Packaging for Laser Systems V}

\author{
Alexei L. Glebov \\ Paul O. Leisher \\ Editors
}

4-6 February 2019

San Francisco, California, United States

Sponsored and Published by

SPIE 
The papers in this volume were part of the technical conference cited on the cover and title page. Papers were selected and subject to review by the editors and conference program committee. Some conference presentations may not be available for publication. Additional papers and presentation recordings may be available online in the SPIE Digital Library at SPIEDigitalLibrary.org.

The papers reflect the work and thoughts of the authors and are published herein as submitted. The publisher is not responsible for the validity of the information or for any outcomes resulting from reliance thereon.

Please use the following format to cite material from these proceedings:

Author(s), "Title of Paper," in Components and Packaging for Laser Systems $V$, edited by Alexei L. Glebov, Paul O. Leisher, Proceedings of SPIE Vol. 10899 (SPIE, Bellingham, WA, 2019) Sevendigit Article CID Number.

ISSN: 0277-786X

ISSN: 1996-756X (electronic)

ISBN: 9781510624405

ISBN: 9781510624412 (electronic)

Published by

SPIE

P.O. Box 10, Bellingham, Washington 98227-0010 USA

Telephone +1 3606763290 (Pacific Time) · Fax +1 3606471445

SPIE.org

Copyright (C) 2019, Society of Photo-Optical Instrumentation Engineers.

Copying of material in this book for internal or personal use, or for the internal or personal use of specific clients, beyond the fair use provisions granted by the U.S. Copyright Law is authorized by SPIE subject to payment of copying fees. The Transactional Reporting Service base fee for this volume is $\$ 18.00$ per article (or portion thereof), which should be paid directly to the Copyright Clearance Center (CCC), 222 Rosewood Drive, Danvers, MA 01923. Payment may also be made electronically through CCC Online at copyright.com. Other copying for republication, resale, advertising or promotion, or any form of systematic or multiple reproduction of any material in this book is prohibited except with permission in writing from the publisher. The CCC fee code is 0277$786 \mathrm{X} / 19 / \$ 18.00$.

Printed in the United States of America by Curran Associates, Inc., under license from SPIE.

Publication of record for individual papers is online in the SPIE Digital Library.

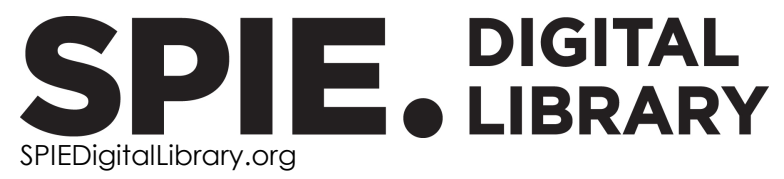

Paper Numbering: Proceedings of SPIE follow an e-First publication model. A unique citation identifier (CID) number is assigned to each article at the time of publication. Utilization of CIDs allows articles to be fully citable as soon as they are published online, and connects the same identifier to all online and print versions of the publication. SPIE uses a seven-digit CID article numbering system structured as follows:

- The first five digits correspond to the SPIE volume number.

- The last two digits indicate publication order within the volume using a Base 36 numbering system employing both numerals and letters. These two-number sets start with $00,01,02,03,04$, 05, 06, 07, 08, 09, OA, OB ... 0Z, followed by 10-1Z, 20-2Z, etc. The CID Number appears on each page of the manuscript. 


\title{
Contents
}

\author{
$\checkmark \quad$ Authors \\ vii Conference Committee
}

DIODE PACKAGING: JOINT SESSION WITH 10899 AND 10890

1089904 Three-dimensional steady-state thermal model of a high power diode laser [10899-3]

1089905 Thermal modelling of laser diode packages [10899-4]

LASER DIODE PACKAGING I

1089906 Single mode $500 \mathrm{~mW}$ at $633 \mathrm{~nm}$ using all semiconductor master oscillator and a dual stage amplifier [10899-5]

1089908 The application of telecoms-style packaging techniques to narrow linewidth laser modules for quantum technologies [10899-7]

1089909 Intelligent simultaneous active sub-micron multi-component alignment for next generation datacom applications [10899-8]

10899 OA Development of high power annular diode laser array using hard solder [10899-9]

\section{LASER DIODE PACKAGING II}

10899 OC Fused silica fast axis collimator lens for blue high-power laser diodes [10899-11]

10899 OD Design and realization of future compact external-cavity diode laser systems [10899-12]

\section{ADVANCED LASER PACKAGING SOLUTIONS}

10899 OF Integrated photonics for NASA applications (Invited Paper) [10899-14]

$10899 \mathrm{OH} \quad$ Spaceflight 100W, 1940nm polarization maintaining Im doped fiber laser for pumping Q-switched 2um Ho:YLF [10899-16] 
HIGH POWER/ENERGY LASER COMPONENTS AND PACKAGING I

$108990 Q \quad$ Impact of angular pump power distribution on double-clad fiber temperature and incidence on high-power fiber laser reliability [10899-25]

10899 OS A simple technique for direct, high power laser beam profile measurement using thermal imagers [10899-27]

HIGH POWER/ENERGY LASER COMPONENTS AND PACKAGING II

10899 OT New self-starting mode locked laser with active phase control (Invited Paper) [10899-28]

HIGH POWER/ENERGY LASER COMPONENTS AND PACKAGING III

1089910 Spectral and concentration dependence of the Verdet coefficient of dysprosium doped germanate glass [10899-35]

EMERGING LASER COMPONENTS

$1089913 \quad$ KYW crystal as a new material for acousto-optic Q-switches [10899-38]

POSTER SESSION

1089917 Irradiation test of graphene saturable absorber in mode-locked Er-fiber laser [10899-42]

$1089919 \quad$ High-index-contrast Bragg gratings fabricated in fluoride fiber with 513-nm femtosecond laser [10899-44]

10899 1 A High efficiency mode field adapters fabricated with $\mathrm{CO}_{2}$ laser splicer [10899-45]

iv 


\section{Authors}

Numbers in the index correspond to the last two digits of the seven-digit citation identifier (CID) article numbering system used in Proceedings of SPIE. The first five digits reflect the volume number. Base 36 numbering is employed for the last two digits and indicates the order of articles within the volume. Numbers start with 00, 01, 02, 03, 04, 05, 06, 07, 08, 09, OA, OB...0Z, followed by 10-12, 20-2Z, etc.

\author{
Abrams, Nathan, OF \\ Arteaga-Sierra, Francisco R., OF \\ Balaswamy, V., OS \\ Baumgärtner, S., OD \\ Bei, Qiang, OF \\ Belzile, P. M., OQ \\ Bergman, Keren, OF \\ Blume, G., 06 \\ Bordenyuk, Andrey, OT \\ Boudreau, S., OQ \\ Bowers, John E., OF \\ Bremner, D., 08 \\ Brown-Dussault, E., $0 Q$ \\ Cai, Lei, OA \\ $\mathrm{CaO}, \mathrm{He}, \mathrm{OH}$ \\ Carson, C., 08 \\ Chavez, Arturo, 10 \\ Chen, Li, OA \\ Chen, Ray T., OF \\ Chizhikov, Alexander I., 13 \\ Dalir, Hamed, OF \\ Datta, Ipshita, OF \\ Ding, Yimin, OF \\ Dorrer, Christophe, OF \\ Dorward, W., 08 \\ Duan, Yao, OF \\ Engin, Doruk, $\mathrm{OH}$ \\ Faucher, D., OQ \\ Faucher, M., OQ \\ Feise, D., 06 \\ Forrer, H., OC \\ Forrer, M., OC \\ Fridlander, Joseph, OF \\ Fu, Tuanwei, OA \\ Gapontsev, Valentin, OT \\ Gong, Songbin, OF \\ Goodman, Luke, OT \\ Goya, K., 19 \\ Gu, Tingyi, OF \\ Harris, James, OF \\ Ho, Seng-Tiong, OF \\ Hou, Dong, OA \\ Huang, Yingyan, OF \\ Huber, M., OC \\ Johansson, Leif, OF \\ Jones, B., 08 \\ Kibben, Simon, 09 \\ Kim, Dohyun, 17 \\ Kim, Jungwon, 17
}

Klamkin, Jonathan, OF

Kolodzie, N., OD

Komljenovic, Tin, OF

Konishi, D., 19

Koyucuoglu, A., 06

Krainak, Michael, OF

Kunkel, John D., 10

Lee, S. T., 08

Leisching, P., OD

Li, Michael, 10

Liang, Xuejie, OA

Lipson, Michal, OF

Litvinovitch, Slava, $\mathrm{OH}$

Liu, Guangyao, OF

Liu, Xingsheng, 04, 0A

Long, Mark, $\mathrm{OH}$

Lozovoy, Vadim $\vee$., OT

Makarevskaya, Elena $\vee ., 13$

Mallick, Monalisa, OS

Matsko, Andrey, OF

Matteo, A., OD

McKnight, L., 08

Meusel, Jens, 05

Molchanov, Vladimir Ya., 13

Mollaee, Masoud, 10

Mookherjea, Shayan, OF

Moser, H., OC

Moslehi, Behzad, OF

Murakami, M., 19

Naumenko, Natalya F., 13

$\mathrm{Ni}$, Xingjie, OF

Nölleke, C., OD

Ohanian, Osgar John, III, OF

Panda, Binodbihari, OS

Park, Nam-Hun, 17

Paschke, K., 06

Pavlyuk, Anatoly A., 13

Pestov, Dmitry, OT

Pohl, J., 06

Poston, William, 10

Proietti, Roberto, OF

Qiao, Jie, OF

Raab, C., OD

Raj, Piyush, OS

Reyna, Baraquiel, OF

Rizzo, Anthony, OF

Robertson, S., 08

Ryabtsev, Anton, OT

Sahm, A., 06 
Samartsev, Igor, OT

Saupe, F., OC

Savchenkov, Anatoliy, OF

Seyfried, Moritz, 09

Song, Bowen, OF

Sorger, Volker J., OF

Spiess, Christopher, 05

Stephen, Mark, OF

Storm, Mark, $\mathrm{OH}$

Sun, Lichen, OA

Supradeepa, V. R., OS

Tedder, Sarah, OF

Tokita, S., 19

Tran, Minh, OF

Troupaki, Elisavet, OF

Tu, Yongming, OF

Uehara, H., 19

Vahrenkamp, Torsten, 09

Vetterlein, Jan, 05

Wang, Jingwei, OA

Wölz, Martin, 05

Wu, Di-Hai, 04

Wuest, P., OC

Yan, Minna, OA

Yang, Yan, $\mathrm{OA}$

Yeom, Dong-II, 17

Yoo, S. J. B., OF

Yushkov, Konstantin B., 13

Zah, Chung-En, 04, OA

Zakharov, Nikita G., 13

Zelmon, David E., 10

Zhao, Hongwei, OF

Zhu, Gongwen, IA

Zhu, Xiushan, 10

Zong, Jie, 10 


\section{Conference Committee}

Symposium Chairs

Beat Neuenschwander, Berner Fachhochschule Technik und Informatik (Switzerland)

Xianfan Xu, Purdue University (United States)

Symposium Co-chairs

Koji Sugioka, RIKEN Center for Advanced Photonics (Japan)

Reinhart Poprawe, Fraunhofer-Institut für Lasertechnik (Germany)

Program Track Chairs

Kunihiko Washio, Paradigm Laser Research Ltd. (Japan)

John Ballato, Clemson University (United States)

Conference Chairs

Alexei L. Glebov, OptiGrate - IPG Photonics Corporation (United States)

Paul O. Leisher, Lawrence Livermore National Laboratory (United States)

Conference Program Committee

Igor Anisimov, Air Force Research Laboratory (United States)

Jens Biesenbach, DILAS Diodenlaser GmbH (Germany)

Gunnar Böttger, Fraunhofer-Institut für Zuverlässigkeit und Mikrointegration

(Germany)

Jenna Campbell, Freedom Photonics, LLC (United States)

Joseph L. Dallas, Avo Photonics, Inc. (United States)

Martin Forrer, FISBA AG (Switzerland)

Manoj Kanskar, nLIGHT Corporation (United States)

Alexander V. Laskin, AdIOptica Optical Systems GmbH (Germany)

Xingsheng Liu, Xi'an Institute of Optics and Precision Mechanics (China)

Christian V. Poulsen, NKT Photonics Inc. (United States)

Mark A. Stephen, NASA Goddard Space Flight Center (United States)

Takunori Taira, Institute for Molecular Science (Japan)

François Trépanier, TeraXion Inc. (Canada)

Torsten Vahrenkamp, ficonTEC Service GmbH (Germany)

Alexander Yusim, IPG Photonics Corporation (United States)

Chung-En Zah, Focuslight Technologies, Inc. (China)

Arnaud Zoubir, ALPhANOV (France) 


\section{Session Chairs}

1 Diode Reliability: Joint Session with 10899 and 10890 Jenna Campbell, Freedom Photonics, LLC (United States)

Erik Zucker, Erik Zucker Consulting (United States)

2 Diode Packaging: Joint Session with 10899 and 10890

Paul O. Leisher, Lawrence Livermore National Laboratory (United States)

Robert Martinsen, nLIGHT, Inc. (United States)

3 Laser Diode Packaging I

Joseph L. Dallas, Avo Photonics, Inc. (United States)

4 Laser Diode Packaging II

Chung-En Zah, Focuslight Technologies, Inc. (China)

$5 \quad$ Advanced Laser Packaging Solutions

Manoj Kanskar, nLIGHT, Inc. (United States)

6 Laser Optics and Optical Assembly

Martin Forrer, FISBA AG (Switzerland)

7 High Power/Energy Laser Components and Packaging I

Alexander Yusim, IPG Photonics Corporation (United States)

8 High Power/Energy Laser Components and Packaging II Christian V. Poulsen, NKT Photonics Inc. (United States)

9 High Power/Energy Laser Components and Packaging III Moritz Seyfried, ficonTEC Service GmbH (Germany)

10 Emerging Laser Components Johan Boullet, ALPhANOV (France) 